\section{Wood-soil interactions in soil bioengineering slope stabilization works}

\author{
Moscatelli MC (1), Romagnoli $M^{(2)}$, Cenfi $S^{(2)}$, Lagomarsino A ${ }^{(1)}$, Di Tizio \\ $A^{(1)}$, Spina $S^{(2)}$, Grego $S^{(1)}$
}

In this work we propose the use of soil quality indicators with the aim of assessing the environmental impact of soil bioengineering works. This study was carried out in central Italy where soil bioengineering slope stabilization works were established using chestnut wood. In particular the goal of this study was to determine the occurrence of a wood-effect, that is changes of soil properties due to the presence of decomposing logs in two sites characterized by different time span since works setting up. The presence of the logs did not affect soil physico-chemical properties. Conversely, soil biochemical properties such as soil microbial biomass, basal and cumulative respiration activities as well as microbial indexes, were influenced by the presence of the logs confirming the role of these bioindicators as early predictors of changes occurring in soil. Although a general positive trend was observed for the biochemical properties at both sites with respect to the control soils, significant differences were recorded mainly at the site where works were established six years before soil sampling. Soil bioengineering slope stabilization works establish a positive feed-back which ultimately can benefit plants; in fact the increase in microbial mineralization activity can enhance nutrient cycling and thus promote adequate growth conditions for the plant cuttings used in the wooden-work.

Keywords: Wood decomposition, Microbial biomass, Microbial respiration, Soil quality, Soil bioengineering

\section{Introduction}

Soil bioengineering uses sound engineering practices in conjunction with integrated ecological principles, using living vegetation and other materials to construct slopes (hillslopes, riverbanks, and lake/shorelines), stabilize slopes, control erosion, protect wildlife habitats and enhance the functioning of ecosystems (Donald \& Robbin 1996, Gray \& Sotir 1996). Successes of ecological engineering make it an increasingly attractive alternative to traditional engineering approaches, which are often much more expensive to construct and sustain ( $\mathrm{Li} \&$ Eddleman 2002). Vegetation can affect the stability of slopes by modifying the hydrological regime in the soil. Species often used in bioenginee-

(1) Dipartimento di Agrobiologia e Agrochimica, Università della Tuscia, Viterbo, Italy; (2) Dipartimento di Tecnologie, Ingegneria e Scienze dell'Ambiente e delle Foreste, Università della Tuscia, Viterbo, Italy

(a), Maria Cristina Moscatelli (mcm@unitus.it)

Received: May 07, 2009 - Accepted: Aug 18, 2009

Citation: Moscatelli MC, Romagnoli M, Cenfi S, Lagomarsino A, Di Tizio A, Spina S, Grego $S$, 2009. Wood-soil interactions in soil bioengineering slope stabilization works. iForest 2: 187-191 [online: 2009-10-15] URL: http://www.sisef.it/iforest/show.php?id=513 ring applications include willow, poplar, grasses and native shrub species anyway usually fast-growth species.

In the last years wood has been widely used as a suitable natural material to be used in soil bioengineering works (Sauli et al. 2002). In particular, among wood characteristics, its mechanical resistance and its duration over time is not always necessary, being its role that of allowing plants colonization in its early stages and so these characteristics are important only in specific situations. Among the various environmental factors influencing the performance of the woodenwork, soil plays an extremely important role. Its properties in fact not only determine by wood decomposition which can deeply affect soil physico-chemical and biochemical features. Another important aspect of soil bioengineering is thus emphasized: soil is an element either active in wood decay or passive, being itself influenced by wood decay. Soil nutrients cycling and availability are indeed deeply affected by wood decay so that decomposing logs have been referred as "slow-release fertilizers" (Carey 1980).

Dead wood is no longer considered as merely debris, and wood decomposition is widely recognized as a key ecological process (Franklin et al. 1987). Decaying wood also plays an important role in soil development because the residues from the degradation of wood decay rate, but are in turn influenced wood components (especially lignin) are one of the substrates for humus formation (Stevenson 1982). Additionally, leaching of dissolved organic matter from decaying wood contributes to the soil organic matter pools and, providing easily available organic substrates, may fuel soil microbial biomass, thus enhancing its size and/or activity (Yavitt \& Fahey 1985, Spears et al. 2003).

However, regarding the effect of decaying wood on the physical, chemical and biochemical properties of the underlying soil, contrasting results were reported and, to our knowledge, not specifically on soil bioengineering works. Some studies found higher $\mathrm{C}$ (carbon) and $\mathrm{N}$ (nitrogen) percentages in soil under decaying wood, but did not observe changes in the C:N ratios (Kayahara et al. 1996), while Hafner et al. (2005) reported higher $\mathrm{C}: \mathrm{N}$ ratio beneath decaying logs.

Further approaches, aimed to infer effects of decaying wood on nutrient availability, have been focused on soil biological properties. Busse (1994) found higher microbial biomass and microbial quotient (ratio of microbial $\mathrm{C}$ to total organic C) under than away from decaying logs in a pine forest in Oregon and suggested it could be the result of higher mineralizable N. Conversely Kayahara et al. 1996 found the opposite, namely higher mineralizable $\mathrm{N}$ away from logs.

As suggested by Klinka et al. (1995), the effect of decaying wood on soil can be specific for each ecosystem, as it is affected by the characteristics of the physical environment as well as by biotic-mediated processes. Furthermore the wood decay stage and thus residence time are extremely important in determining the amplitude of these effects. In the last 20 years many properties (physical, chemical and biochemical) have been recognized as indicators of changes occurring within the soil system. In particular, the bioindicators (representing features related to the living component of the soil, mainly the microbial biomass and its metabolic activity) have been considered particularly reliable as early predictors of modifications affecting the soil environment (Gil-Sotres et al. 2005). Specifically microbial pool and its activity have a central role in the soil biogeochemical cycling, thus determining the potential availability of mineral nutrients for plants growth (Lagomarsino et al. 2008, Moscatelli et al. 2008).

The aim of this study was to outline a wood-effect, that is changes in soil properties due to wood degradation, that in turn can affect nutrient cycling and soil microrganisms activity and size (Yavitt \& Fahey 1985, Hafner et al. 2005). This was studied in two sites characterized by different length of time since works setting up. In particular the effectiveness of the different soil indicators (physi- 


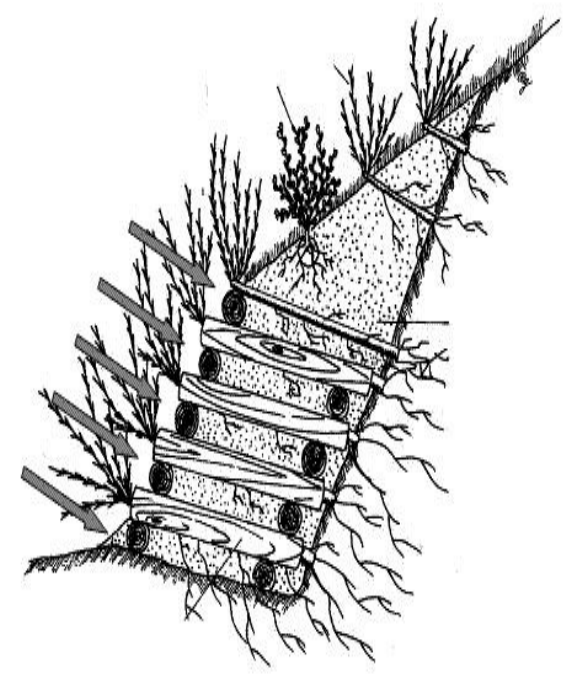

Fig. 1 - Drawing of the double wooden pilecaissons realized at Atina and Barbarano. The six grey arrows indicate where soil cores were sampled. Modified from Sauli et al (2006).

co-chemical and biochemical) was evaluated.

\section{Material and methods}

Sites description and soil sampling

This study was conducted in central Italy where bioengineering slope stabilization works, using chestnut wood, were established in two sites: Atina, in the province of Frosinone and Barbarano Romano in the province of Viterbo.

Barbarano Romano (340 a.s.1., 42 ${ }^{\circ} 15^{\prime} 1$ ' N, $12^{\circ} 4^{\prime} 3$ ” E) natural reserve is located in the province of Viterbo, Central Italy. Annual precipitation is $1050 \mathrm{~mm}$ and average annual temperature is $13^{\circ} \mathrm{C}$.

The typical riparian vegetation is characterized by allochtonous species of Robinia pseudacacia L. e Ailanthus altissima Mill. The double wooden pile-caisson was $1.4 \mathrm{~m}$ high and $3 \mathrm{~m}$ long. It has been built with debarked chestnut logs (Castanea sativa Mill.) of $14 \mathrm{~cm}$ diameter.

Atina, Colle Melfa (450 m a.s.1., 41'37'0"' $\left.\mathrm{N}, 13^{\circ} 48^{\prime} 0^{\prime \prime} \mathrm{E}\right)$ is located in the province of Frosinone, Central Italy. Annual precipitation is $1460 \mathrm{~mm}$ and average annual temperature is $13.6^{\circ} \mathrm{C}$. Dominant tree species include Quercus pubescens Will., Robinia pseudoacacia L., Salix alba L. and Populus alba $\mathrm{L}$. The double wooden pile-caisson was $2.4 \mathrm{~m}$ high and $3 \mathrm{~m}$ long. It has been built with debarked chestnut logs (Castanea sativa Mill.) of $25 \mathrm{~cm}$ diameter. In both woodenworks autochthonous cuttings of Salix purpurea L. and Salix eleagnos L. were used. A schematic drawing of the double wooden pile-caisson realized at Barbarano and Atina and soil sampling scheme is presented in Fig. 1.

Soil sampling was carried out at both sitesin November 2007, two and six years later since the double wooden pile-caisson establishment respectively. Six soil samples were collected at $0-10 \mathrm{~cm}$ depth directly beneath six logs of the double wooden pilecaisson in both sites (log soils, LS - Fig. 1). In order to account for a wood-effect and to eliminate differences due to other factors such as the pedogenetic characteristics of both sites, six corresponding soils cores, named control soils (CS), were sampled at the same depth at least $5 \mathrm{~m}$ away from the double wooden pile-caisson at each site in ab-

Tab. 1 - Physico-chemical properties of the soils at Barbarano Romano and Atina measured in control soils (CS) and beneath the logs (LS). Standard error of mean is reported $(n=6)$. $(*)$ : $\mathrm{p}<0.05 ;(* *): \mathrm{p}<0.01 ;(* * *): \mathrm{p}<0.001$, ns: not significant.

\begin{tabular}{|c|c|c|c|c|}
\hline \multirow{2}{*}{ Parameters } & \multicolumn{2}{|c|}{ Atina } & \multicolumn{2}{|c|}{ Barbarano Romano } \\
\hline & CS & LS & CS & $\mathbf{L S}$ \\
\hline Texture & \multicolumn{2}{|c|}{ Loam, Sandy-loam } & \multicolumn{2}{|c|}{ Sand, Loamy-sand } \\
\hline Moisture (\%) & $16.28 \pm 1.3$ & $14.90 \pm 0.9$ & $17.61 \pm 1.8$ & $20.69 \pm 1.9$ \\
\hline TOC (\%) & $2.61 \pm 0.4$ & $2.31 \pm 0.2$ & $1.82 \pm 0.2$ & $1.60 \pm 0.1$ \\
\hline TN (\%) & $0.16 \pm 0.02$ & $0.18 \pm 0.01$ & $0.22 \pm 0.03$ & $0.17 \pm 0.03$ \\
\hline $\mathrm{C}: \mathrm{N}$ ratio & $12.73 \pm 0.9$ & $12.96 \pm 0.5$ & $8.69 \pm 1.02$ & $10.24 \pm 0.89$ \\
\hline $\mathrm{pH}_{\mathrm{H} 20}$ & $7.31 \pm 0.01$ & $7.34 \pm 0.1$ & $7.64 \pm 0.07$ & $7.68 \pm 0.06$ \\
\hline $\mathrm{pH}_{\mathrm{KCl}}$ & $7.07 \pm 0.04$ & $7.03 \pm 0.04$ & $6.88 \pm 0.05$ & $6.90 \pm 0.06$ \\
\hline \multicolumn{5}{|c|}{ Analysis of variance } \\
\hline \multicolumn{2}{|c|}{ Parameters } & Site & Logs presence & Site $x$ Logs \\
\hline Moisture & & $*$ & ns & ns \\
\hline TOC & & $*$ & ns & ns \\
\hline $\mathrm{TN}$ & & ns & ns & ns \\
\hline $\mathrm{C}: \mathrm{N}$ ratio & & $* *$ & ns & ns \\
\hline $\mathrm{pH}_{\mathrm{H} 20}$ & & $* * *$ & ns & ns \\
\hline $\mathrm{pH}_{\mathrm{KCl}}$ & & $* *$ & ns & $\mathrm{ns}$ \\
\hline
\end{tabular}

sence of perennial vegetation, for a total of 12 soils per site. Soil samples were immediately sieved $(<2 \mathrm{~mm})$ and the moisture content adjusted to $60 \%$ of their water holding capacity (WHC). The soil samples were then left to equilibrate at room temperature in the dark for $12 \mathrm{~h}$ prior to biochemical analyses.

\section{Soil physico-chemical and biochemical properties}

Soil texture was determined following the pipette method (Patrino et al. 1997). Organic $\mathrm{C}\left(\mathrm{C}_{\mathrm{org}}\right)$ and total $\mathrm{N}\left(\mathrm{N}_{\mathrm{tot}}\right)$ were determined on $20 \mathrm{mg}$ of oven dry soil. The method was based on dry combustion using an elemental analyser (Thermo Soil NC - Flash EA1112).

Active and exchangeable acidity were measured on sieved soil suspended in a solution of deionised water (active) or in $\mathrm{KCl} 1 \mathrm{~N}$ (exchangeable) in 1:2.5 ratio. The $\mathrm{pH}$ was measured in the supernatant with a $\mathrm{pH}$ meter $(\mathrm{pH}$ 211, Hanna Instruments).

Microbial biomass carbon (MBC) was estimated following the Fumigation Extraction (FE) method: two portions of moist soil (20 g oven-dry soil) were weighed, the first one (not fumigated) was immediately extracted with $80 \mathrm{ml}$ of $0.5 \mathrm{M} \mathrm{K}_{2} \mathrm{SO}_{4}$ for $30 \mathrm{~min}$ by oscillating shaking at $200 \mathrm{rpm}$ and filtered (Whatman n. 42); the second one was fumigated for $24 \mathrm{~h}$ at $25^{\circ} \mathrm{C}$ with ethanol-free $\mathrm{CH}-$ $\mathrm{Cl}_{3}$ and then extracted as described above. Organic $\mathrm{C}$ in the extracts was determined after oxidation with $0.4 \mathrm{~N} \mathrm{~K}_{2} \mathrm{Cr}_{2} \mathrm{O}_{7}$ at $100^{\circ} \mathrm{C}$ for $30 \mathrm{~min}$ (Vance et al. 1987). Microbial biomass was calculated as follows (eqn. 1):

\section{Biomass $C=E C / k E C$}

where $E_{\mathrm{C}}$ is the difference between organic $\mathrm{C}$ extracted from fumigated soils and organic $\mathrm{C}$ extracted from not fumigated soils and $k_{\mathrm{EC}}=$ 0.38 . C extracted from not fumigated samples represents the labile pool of $\mathrm{K}_{2} \mathrm{SO}_{4}$ extractable C (ExtC).

For measuring microbial respiration $20 \mathrm{~g}$ (oven-dry basis) of moist sample were placed in $1 \mathrm{~L}$ stoppered glass jars. The $\mathrm{CO}_{2}$ evolved was trapped, after 1, 3, 7, 10, 14, 21, 28 days of incubation, in $2 \mathrm{ml} 1 \mathrm{M} \mathrm{NaOH}$ and determined by titration of the excess $\mathrm{NaOH}$ with $0.1 \mathrm{M} \mathrm{HCl}$ (Badalucco et al. 1992). The potential initial mineralization rate $\left(\mathrm{C}_{0} k\right)$ was calculated from the kinetic parameters obtained using the mineralization kinetic model of C (Riffaldi et al. 1996 - eqn. 2):

$$
C_{m}=C_{0}\left(1-e^{-k t}\right)
$$

The hourly $\mathrm{CO}_{2}$ evolved after the $10^{\text {th }}$ day of incubation was used as the basal respiration value because, after that period, the soil reached a relatively constant hourly $\mathrm{CO}_{2}$ production rate.

The metabolic quotient $\left(q \mathrm{CO}_{2}\right)$ is calculated as $\mu \mathrm{g} \mathrm{C}-\mathrm{CO}_{2}$ basal $\mathrm{h}^{-1} \mu \mathrm{g}$ Biomass $\mathrm{C}^{-1}$ following Dilly \& Munch (1998) and is a bioindicator used as a measure of disturbance or 
Tab. 2 - Biochemical properties of the soils at Atina and Barbarano Romano measured in control soils (CS) and beneath the logs (LS). ExtC, MBC, Basal and cumulative respiration are expressed as fractions of total organic carbon (TOC). Analysis of variance is calculated for the following factors and interactions: site and logs presence. Standard error of mean is reported $(n=6)$.

\begin{tabular}{|c|c|c|c|c|}
\hline \multirow{2}{*}{ Parameters } & \multicolumn{2}{|c|}{ Atina } & \multicolumn{2}{|c|}{ Barbarano Romano } \\
\hline & CS & LS & CS & LS \\
\hline $\begin{array}{l}\text { ExtC } \\
\left(\mu \mathrm{g} \mathrm{C} \mu \mathrm{g} \mathrm{TOC}^{-1} \mathrm{~g}^{-1}\right) 10^{2}\end{array}$ & $0.20 \pm 0.05$ & $0.39 \pm 0.1$ & $0.36 \pm 0.04$ & $0.42 \pm 0.02$ \\
\hline $\begin{array}{l}\text { MBC } \\
\left(\mu \mathrm{g} \text { Biomass } \mathrm{C} \mu \mathrm{g} \mathrm{TOC}^{-1} \mathrm{~g}^{-1}\right) 10^{2}\end{array}$ & $0.77 \pm 0.1$ & $1.28 \pm 0.2$ & $0.85 \pm 0.14$ & $1.04 \pm 0.07$ \\
\hline $\begin{array}{l}\text { Bas. Resp. } \\
\left(\mu \mathrm{g} \mathrm{C}-\mathrm{CO}_{2} \mathrm{~h}^{-1} \mu \mathrm{g} \mathrm{TOC}^{-1} \mathrm{~g}^{-1}\right) 10^{4}\end{array}$ & $0.48 \pm 0.1$ & $0.89 \pm 0.1$ & $0.64 \pm 0.03$ & $0.93 \pm 0.08$ \\
\hline $\begin{array}{l}\text { Cum. Resp. } \\
\left(\mu \mathrm{g} \mathrm{C}-\mathrm{CO}_{2} \mu \mathrm{gTOC}^{-1} \mathrm{~g}^{-1}\right) 10^{2}\end{array}$ & $3.44 \pm 0.6$ & $5.88 \pm 0.6$ & $4.15 \pm 0.23$ & $5.23 \pm 0.20$ \\
\hline $\begin{array}{l}q \mathrm{CO}_{2} \\
\left(\mu \mathrm{g} \mathrm{C}-\mathrm{CO}_{2} \mu \mathrm{g} \text { Biom. } \mathrm{C}^{-1} \mathrm{~g}^{-1}\right) 10^{3}\end{array}$ & $6.94 \pm 0.8$ & $6.66 \pm 0.4$ & $5.72 \pm 0.54$ & $8.04 \pm 0.63$ \\
\hline $\begin{array}{l}\mathrm{C}_{0} \mathrm{~K} \\
\left(\mu \mathrm{g} \mathrm{C} \mathrm{CO}_{2} \mathrm{~g}^{-1} \mathrm{day}^{-1}\right) \\
\end{array}$ & $35.0 \pm 3.0$ & $59.0 \pm 3.8$ & $44.8 \pm 6.1$ & $46.2 \pm 6.8$ \\
\hline \multicolumn{5}{|c|}{ Analysis of variance } \\
\hline Parameters & & Site & Logs & Site x Logs \\
\hline$\overline{\mathrm{ExtC}}$ & & ns & $*$ & $*$ \\
\hline $\mathrm{MBC}$ & & ns & $*$ & $\mathrm{~ns}$ \\
\hline Bas. Resp. & & ns & $* * *$ & ns \\
\hline Cum. Resp. & & ns & $* *$ & ns \\
\hline$q \mathrm{CO}_{2}$ & & ns & ns & $*$ \\
\hline $\mathrm{C}_{0} \mathrm{~K}$ & & ns & $*$ & $*$ \\
\hline
\end{tabular}

presence of the wooden-work at both sites (Tab. 1). Soil extractable C, microbial biomass $\mathrm{C}$ content, basal and cumulative respiration, expressed as fractions of total organic carbon, metabolic quotient $\left(q \mathrm{CO}_{2}\right)$ and the potential initial mineralization rate $\left(\mathrm{C}_{0} \mathrm{~K}\right)$ are reported in Tab. 2. No significant differences were ascribable to the different sites; however the presence of the logs significantly affected most of these properties although, only in few cases, in interaction with the site (Tab. 2). The wood-effect on extractable C, microbial biomass, basal and cumulative respiration and microbial indexes $\left(q \mathrm{CO}_{2}\right.$ and $\mathrm{C}_{0} \mathrm{~K}$ ) is presented in Fig. 2. Graphs show the percentage variation of each biochemical property in the soil beneath the logs (LS) with respect to the control soil (CS) at Atina (Fig. 2a) and Barbarano Romano (Fig. 2b). At Atina, with the exception of the metabolic quotient, all the parameters show a positive and significant increase due to the presence of the decomposing wood $(+75 \%$ as an average value). At Barbarano a general positive trend of the wood-effect was also observed, though a significant increase was recorded only for the basal and cumulative respiration and the metabolic quotient $(+44,+26$ and $+40 \%$, respectively).

\section{Discussion}

The effect of decaying wood on the physi- stress conditions of microbial biomass (Anderson 2003).

Considering the differences in soil organic matter content at both sites the biochemical properties have been presented as fractions $(\%)$ of total organic $\mathrm{C}$. The use of these quotients avoids the problems of comparing trends in soils with different organic matter content (Sparling 1997) and appears to provide more sensitive indications of soil changes than either activity or population measurements alone (Dilly \& Munch 1998).

The wood-effect is presented as the percentage variation of each biochemical parameter measured in the soil beneath the logs (LS) with respect to the relative control soil (CS).

\section{Statistical analysis}

Analysis of variance (ANOVA) and Bonferroni post-hoc test were performed to evaluate the main effects of site, logs presence and their interactions on the parameters analysed. Statistical analysis was performed using SYSTAT 11.0, a statistical probability of $\mathrm{p}<0.05$ was considered as significant.

\section{Results}

Soil physico-chemical properties of Atina and Barbarano sites are reported in Tab. 1. Atina shows a higher content of soil organic carbon and lower values of soil $\mathrm{pH}$. However, no significant changes of soil physicochemical properties were detected due to the
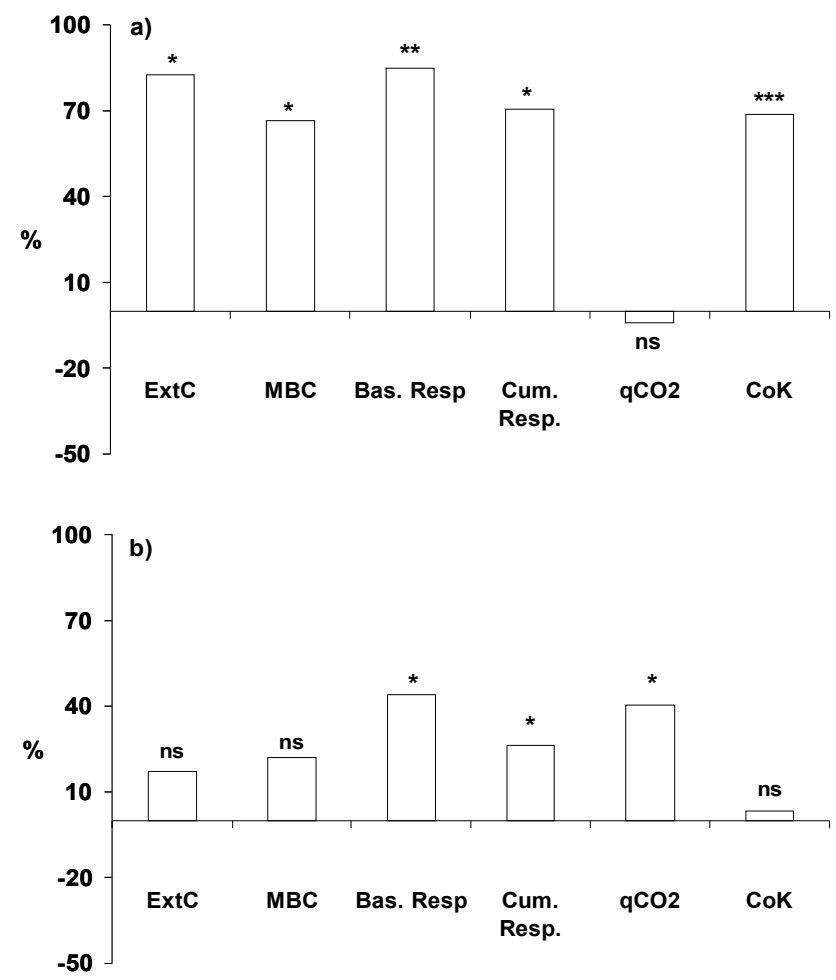

Fig. 2 - Wood-effect calculated as mean percentage variation of extractable $\mathrm{C}$ (ExtC), microbial biomass $\mathrm{C}(\mathrm{MBC})$, basal respiration, cumulative respiration, metabolic quotient $\left(q \mathrm{CO}_{2}\right)$ and initial potential mineralization rate $\left(\mathrm{C}_{0} \mathrm{~K}\right)$ measured in the soil beneath the logs with respect to control soils at Atina (a) and Barbarano (b). (*): p $<0.05 ;(* *)$ : $p<0.01 ;(* * *)$ : $\mathrm{p}<0.001$; ns: not significant. 
cal, chemical and biochemical properties of the underlying soil was reported by several studies (Busse 1994, Kayahara et al. 1996 , Krzyszowska-Waitkus \& Vance 1999, Spears et al. 2003, Hafner et al. 2005, Zalamea et al. 2007, Kappes et al. 2007) however, to our knowledge, no specific investigations have been done on wooden-work deterioration effects on soil biological features. Thus, our results represent a new field of research aimed to assess the environmental impact of soil bioengineering works.

As regards of soils physico-chemical properties, no significant differences were found at our experimental sites on soil moisture, $\mathrm{pH}, \mathrm{C}$ and $\mathrm{N}$ content in the soil beneath and away from the logs. A lack of effect on soil moisture can be related to the early decay stage of the logs; in fact, Harmon \& Sexton 1995 reported that a high degree of decay, particularly with degradation of sapwood and heartwood, allows higher infiltration rates of water thus modifying soil humidity.

Kayahara et al. (1996) and Hafner et al (2005) reported higher $\mathrm{C}: \mathrm{N}$ ratios in the soil under decomposing wood, due to increases in total $\mathrm{C}$ coupled with decreases of total $\mathrm{N}$ and indicating that decaying wood can represent a source of recalcitrant organic matter. We did not observe significant variations of soil $\mathrm{C}$ and $\mathrm{N}$ content and of the $\mathrm{C}: \mathrm{N}$ ratio However, a positive significant effect on the extractable $\mathrm{C}\left(\mathrm{K}_{2} \mathrm{SO}_{4}\right.$-extractable $\left.\mathrm{C}\right)$ at Atina provided evidence of an increased flux of soluble $\mathrm{C}$ forms deriving from the logs; this process is probably at its beginning and accumulation in stable $\mathrm{C}$ fractions cannot so far be highlighted. We did not register changes of soil $\mathrm{pH}$ suggesting that, at this decomposition stage, no leaching of acidic dissolved organic matter from decaying wood - as reported by Klinka et al. (1995) - is occurring.

Conversely, a general positive wood-effect on soil biochemical properties was found in this study at both sites. Microbial biomass and its mineralization activity are widely considered "early warning" of changes occurring in soil and are thus used as reliable bioindicators of soil quality. Indeed, soil physico-chemical parameters alter only when the soil is subjected to really drastic changes (Filip 2002), while biochemical parameters are more sensitive even to sligh modifications of soil environment (Nannipieri et al. 1990, Yakovchenko et al. 1996).

Decaying wood can affect soil microbiota providing labile $\mathrm{C}$ and/or N sources. Severa studies report increase of microbial biomass $\mathrm{C}: \mathrm{N}$ ratio and denitrification activity (Hafner et al. 2005), increase of microbial biomass $C$ and of microbial quotient ( $q$ mic - Busse 1994), increase of non symbiotic N-fixing bacteria (Hendrickson 1994). Conversely, Zalamea-Bustillo 2005 did not find any difference in soil microbial biomass size in soils under decomposing logs when compared to control soils. However, the substrate induced respiration (SIR) method used in that work does not provide a complete assessment of microbial biomass but only the amount of the glucose responsive microorganisms. Furthermore, decay of wood under aerobic conditions results mainly from the action of fungi, while bacteria are the primary degraders of wood under oxygen limiting conditions (Powell et al. 2001). In our study the microbial biomass increased in LS at both sites; however, this increase was significant only at Atina (+66\%) where microbial biomass was positively correlated to $\operatorname{ExtC}(r=0.536, p<0.01)$, confirming that the enhanced flux of soluble $\mathrm{C}$ forms favoured microbial $\mathrm{C}$ immobilization. Furthermore, the ratio of microbial biomass to total organic carbon is an index of substrate availability to the soil microflora (Brookes 1995) and can thus predict a future $\mathrm{C}$ accumulation trend (Anderson \& Domsch 1989).

As for microbial metabolic activity only data on $\mathrm{N}$ mineralization were found in the literature: Busse (1994) reported higher mineralizable $\mathrm{N}$ under decaying logs, while Kayahara et al. (1996) found the opposite, namely higher mineralizable $\mathrm{N}$ away from logs. We measured microbial $\mathrm{C}$ mineralization activity: higher rates of basal and cumulative respiration were found beneath the logs at Atina and Barbarano promoting at both sites a significant wood-effect. Moreover, at Atina we could observe a significant increase of $\mathrm{C}_{0} k$, an indicator of the degree of availability, as well as differences between the mineralized organic compounds (Riffaldi et al. 1996). This index has been proved to be effective for identifying the relationship between the decomposition kinetics of different types of residues and their chemical composition (Saviozzi et al. 2001).

The metabolic quotient is an ecophysiological index informing on stress conditions of the microbial community: in fact, an increase of $q \mathrm{CO}_{2}$ suggests a disturbance affecting microbial maintenance energy (Anderson 2003). $q \mathrm{CO}_{2}$ values were significantly higher in LS only at the Barbarano site, indicating an alteration of microbial ecophysiological performances due to the recent establishment of the wooden works; as for the Atina site the metabolic quotient did not change proving that, after six years, soil microbes shifted the energy supply to biosynthesis processes as the increase of microbial biomass $\mathrm{C}$ showed.

\section{Conclusions}

The use of soil quality indicators was effective to assess the environmental impact of soil bioengineering works. In particular soil biochemical properties (microbial biomass, respiration and microbial indexes) were more responsive than soil physico-chemical characteristics in outlining effects due to wood decomposition. Increases of microbial mineralization activity can positively affect nutrient cycling and an improvement of soil fertility can promote adequate growth conditions for the plant cuttings used in the wooden-work. However the length of time since the double wooden pile-caisson were established determined the amplitude and thus the significance of the wood-effect recorded at both sites.

\section{Acknowledgements}

The authors are grateful to Ing. P. Cornelini for suggesting the case-studies at Atina and Barbarano Romano.

\section{References}

Anderson TH (2003). Microbial eco-physiological indicators to assess soil quality. Agriculture. Ecosystems and Environment 98: 285-293. - doi: 10.1016/S0167-8809(03)00088-4

Anderson TH, Domsch KH (1989). Ratios of microbial biomass carbon to total organic-C in arable soils. Soil Biology and Biochemistry 21: 471479. - doi: 10.1016/0038-0717(89)90117-X

Badalucco L, Grego S, Dell'Orco S, Nannipieri P (1992). Effect of liming on some chemical, biochemical and microbiological properties of acid soil under spruce (Picea abies L.). Biology and Fertility of Soil 14: 76-83. - doi: 10.1007/ BF00336254

Brookes PC (1995). The use of microbial parameters in monitoring soil pollution by heavy metals. Biology and Fertility of Soil 19: 269-279. - doi: 10.1007/BF00336094

Busse MD (1994). Downed bole-wood decomposition in lodgepole pine forests of central Oregon. Soil Science Society of America Journal 581: 221-227. [online] URL: http://soil.scijournals.org/cgi/content/abstract/58/1/221

Carey ML (1980). Whole tree harvesting in Sitka spruce: possible implications. Irish Forestry 37 (1): 48-63. [online] URL: http://www.osti.gov/ energycitations/product.biblio.jsp? osti id $=6395337$

Dilly O, Munch JC (1998). Ratios between estimates of microbial biomass content and microbial activity in soils. Biology and Fertility of Soil 27: 374-379. - doi: 10.1007/s003740050446 Donald HG, Robbin BS (1996). Biotechnical and soil bioengineering slope stabilization: a practical guide for erosion control. A Wiley-Interscience Publication, New York, USA.

Filip Z (2002). International approach to assessing soil quality by ecologically-related biological parameters. Agriculture, Ecosystems and Environment 88: 169-174. - doi: 10.1016/S01678809(01)00254-7

Franklin JR, Shugart HH, Harmon ME (1987). Tree death as an ecological process. BioScience 37: 550-556. - doi: 10.2307/1310665

Gil-Sotres F, Trasar-Cepeda C, Leiros MC, Seoane S (2005). Different approaches to evaluating soil quality using biochemical properties. Soil Biology and Biochemistry 37: 877-887. - doi: 10.1016/ 
j.soilbio.2004.10.003

Gray DH, Sotir RB (1996). Biotechnical and soil bioengineering slope stabilization: a practical guide for erosion control. Wiley, New York, USA.

Hafner SD, Groffman PM, Mitchell MJ (2005). Leaching of dissolved organic carbon, dissolved organic nitrogen, and other solutes from coarse woody debris and bitter in a mixed forest in New York State. Biogeochemistry 74: 257-282. - doi: 10.1007/s10533-004-4722-6

Harmon ME, Sexton J (1995). Water balance of conifer logs in early stages of decomposition. Plant and Soil 172: 141-52. - doi: 10.1007/ BF00020868

Hendrickson OQ (1994). Abundance and activity of $\mathrm{N}_{2}$-Fixing bacteria in decaying wood. Canadian Journal of Forest Research 21: 1299-1304. doi: $10.1139 / \mathrm{x} 91-183$

Kappes H, Catalano C, Topp W (2007). Coarse woody debris ameliorates chemical and biotic soil parameters of acidified broad-leaved forests. Applied Soil Ecology 36: 190-198. - doi 10.1016/j.apsoil.2007.02.003

Kayahara GJ, Klinka K, Lavkulich LM (1996). Effects of decaying wood on evaluation, podzolization, acidification, and nutrition in soils with different moisture regimes. Environmental Monitoring and Assessment 39: 485-492. - doi: 10.1007/ BF00396163

Klinka K, Lavkulich LM, Wang Q, Feller MC (1995). Influence of decaying wood on chemical properties of forest floors and surface mineral soils: a pilot study. Annales of Forest Science 52 523-533. - doi: 10.1051/forest:19950601

Krzyszowska-Waitkus AJ, Vance GF (1999). Influence of coarse woody debris on soil organic substance in a lodgepole pine forest. Agronomy Abstracts 91: 306-308.

Lagomarsino A, Moscatelli M C, Hoosbeek M, De Angelis P, Grego S (2008). Assessment of soil nitrogen and phosphorous availability under elevated $\mathrm{CO}_{2}$ and $\mathrm{N}$-fertilization in a short rotation poplar plantation. Plant and Soil 1-2: 131-147. doi: 10.1007/s11104-008-9614-4

Li MH, Eddleman KE (2002). Biotechnical engineering as an alternative to traditional engineering methods: a biotechnical streambank stabilization design approach. Landscape Urban Plan 60: 225-242. - doi: 10.1016/S01692046(02)00057-9

Moscatelli MC, Lagomarsino A, De Angelis P, Grego S (2008). Short- and medium-term contrasting effects of nitrogen fertilization on $\mathrm{C}$ and $\mathrm{N}$ cycling in a poplar plantation soil. Forest Ecology and Management 255: 447-454. - doi: 10.1016/j.foreco.2007.09.012

Nannipieri P, Ceccanti B, Grego S (1990). Ecological significance of biological activity in soil. In: "Soil biochemistry", vol. 6 (Bollag JM, Stotzky G eds). Marcel Dekker, New York, USA, pp. 293-355.

Patrino A, Cavazza L, Castrignanò A (1997). Granulometria. Metodi di analisi fisica del suolo. Parte III. Edizioni Ministero dell'Agricoltura e Foreste, Rome, Italy.

Powell KL, Pedley S, Daniel G, Corfield M (2001). Ultrastructural observations of microbial succession and decay of wood buried at a Bronze Age archaeological site. International Biodeterioration \& Biodegradation 47: 165-173. - doi: 10.1016/S0964-8305(01)00045-2

Riffaldi R, Saviozzi A, Levi-Minzi R (1996). Carbon mineralization kinetics as influenced by soil properties. Biology and Fertility of Soil 22: 293298. - doi: 10.1007/BF00334572

Sauli G, Cornelini P, Preti F (2002). Manuale di ingnegneria naturalistica. Applicabile al settore idraulico. Assessorato all'ambiente, Dipartimento ambiente e protezione civile, Regione Lazio, Rome, Italy.

Sauli G, Cornelini P, Preti F (2006). Manuale di ingegneria naturalistica-sistemazione dei versanti. Vol. III. Assessorato all'ambiente, Dipartimento ambiente e protezione civile, Regione Lazio, Rome, Italy.
Saviozzi A, Levi-Minzi R, Cardelli R, Riffaldi R (2001). A comparison of soil quality in adjacent cultivated, forest and native grassland soils. Plant and Soil 233: 251-259. - doi: 10.1023/ A:1010526209076

Sparling GP (1997). Soil microbial biomass, activity and nutrient cycling as indicators of soil health. In: "Biological indicators of soil health" (Pankhurst CE, Doube BM, Gupta VVSR eds). CAB International, Wallingford, USA, pp. $97-$ 119.

Spears JDH, Holub SM, Harmon ME, Lajtha K (2003). The influence of decomposing logs on soil biology and nutrient cycling in an old-growth mixed coniferous forest in Oregon, USA. Canadian Journal of Forest Research 33: 21932201. - doi: 10.1139/x03-148

Stevenson FJ (1982). Humus chemistry - genesis, composition and reactions. John Wiley and Sons, New York, USA.

Vance ED, Brookes PC, Jenkinson DS (1987). An extraction method for measuring soil microbial biomass C. Soil Biology and Biochemistry 19: 703-707. - doi: 10.1016/0038-0717(87)90052-6

Yakovchenko VI, Sikora LJ, Rauffman DD (1996). A biologically based indicator of soil quality. Biology and Fertility of Soils 21: 245251. - doi: 10.1007/BF00334899

Yavitt JB, Fahey TJ (1985). Chemical composition of interstitial water in decaying lodgepole pine bole wood. Canadian Journal of Forest Research 15: 1149-1153. - doi: 10.1139/x85-186

Zalamea-Bustillo M (2005). Soil biota, nutrients, and organic matter dynamics under decomposing wood. PhD thesis, Department of Biology, Faculty of natural sciences, University of Puerto Rico. Rio Pedras Compres, pp. 136.

Zalamea M, Gonzàles G, Ping CL, Michaelson G (2007). Soil organic matter dynamics under wood in a subtropical wet forest: effect of tree species and decay stage. Plant and Soil 296: $173-$ 185. - doi: 10.1007/s11104-007-9307-4 